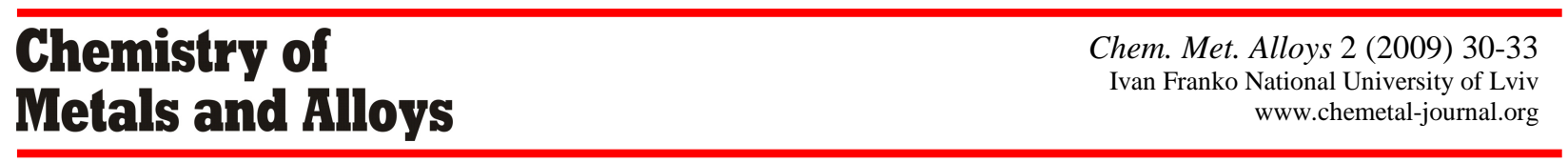

\title{
An investigation of the Al-rich region of the Al-Cu-Ir phase diagram
}

\author{
D. KAPUSH ${ }^{1} *$ B. GRUSHKO ${ }^{2}$, D. PAVLYUCHKOV ${ }^{1}$, T.Ya. VELIKANOVA ${ }^{1}$ \\ ${ }^{1}$ I.N. Frantsevich Institute for Problems of Materials Science, 03680 Kiev 142, Ukraine \\ ${ }^{2}$ Institut für Festkörperforschung, Forschungszentrum Jülich GmbH, D-52425 Jülich, Germany \\ * Corresponding author. Tel: +38-044-4243090; fax: +38-044-4242131; e-mail: d.kapush@gmail.com
}

Received February 2, 2009; accepted June 10, 2009; available on-line November 16, 2009

The Al-Cu-Ir alloy system was studied in the range above 35 at.\% Al. Partial 900 and $540^{\circ} \mathrm{C}$ isothermal sections were determined. Congruent equiatomic AlIr extends at approximately constant $\mathrm{Al}$ concentration up to 30 at.\% $\mathrm{Cu}$. Cubic $\mathrm{C}_{-\mathrm{Al}_{2.7} \mathrm{Ir}}$ (C-phase) dissolves up to 12 at.\% $\mathrm{Cu}, \mathrm{Al}_{3} \mathrm{Ir}$ up to 8.5 at.\% $\mathrm{Cu}_{2} \mathrm{Al}_{28} \mathrm{Ir}_{9}(\chi-$ phase) and $\mathrm{Al}_{45} \mathrm{Ir}_{13}$ ( $\varphi$-phase) up to 3 at. $\% \mathrm{Cu}$, and $\mathrm{Al}_{9} \mathrm{Ir}_{2}$ up to 2.5 at.\% $\mathrm{Cu}$. Increase of the $\mathrm{Cu}$ concentration results in a decrease of the $\mathrm{Al}$ concentration of these phases. The $\mathrm{Al}-\mathrm{Cu} \mathrm{\epsilon}_{1}$-phase dissolves up to 3 at.\% Ir, while the solubility of $\mathrm{Ir}$ in $\theta$ and $\eta_{2}$ is below 0.5 at.\%. Close to the high-Cu limit of the C-phase region an fcc $\mathrm{C}_{2}$-phase $(\mathrm{Fm} \overline{3}, a=1.53928 \mathrm{~nm})$ structurally related to the $\mathrm{C}$-phase is formed. A stable decagonal phase $\left(\mathrm{D}_{1^{-}}\right.$ phase) is formed below $1002^{\circ} \mathrm{C}$ in a compositional range extending from $\mathrm{Al}_{61.5} \mathrm{Cu}_{20} \mathrm{Ir}_{18.5}$ to $\mathrm{Al}_{59} \mathrm{Cu}_{25.5} \mathrm{Ir}_{15.5}$. $\mathrm{A}$ ternary orthorhombic $\varepsilon_{6}$-phase $(a=2.34 \mathrm{~nm}, b=1.65 \mathrm{~nm}, c=1.24 \mathrm{~nm})$ was found below $\sim 1200^{\circ} \mathrm{C}$ in a compositional range extending from $\mathrm{Al}_{71.5} \mathrm{Cu}_{6} \mathbf{I r}_{22.5}$ to $\mathrm{Al}_{68} \mathrm{Cu}_{12.5} \mathrm{Ir}_{19.5}$. An additional ternary $\omega$-phase $(P 4 / m n c, a=0.6414 \mathrm{~nm}, c=1.4842 \mathrm{~nm})$ forming around the $\mathrm{Al}_{70} \mathrm{Cu}_{20} \mathrm{Ir}_{10}$ composition below $683^{\circ} \mathrm{C}$ was revealed.

Phase diagram / Intermetallics / Quasicrystals

\section{Introduction}

This work continues an investigation of the Al-rich part of the Al-Cu-Ir alloy system, which was carried out in [1], following the first report on the formation of stable quasicrystals in $\mathrm{Al}_{65} \mathrm{Cu}_{20} \mathrm{Ir}_{15}$ [2]. The $\mathrm{Al}-\mathrm{Cu}-\mathrm{Ir}$ alloy system belongs to a group of Al-based systems where quasicrystals and related periodic phases have been extensively studied for two decades (see [3] for references). Also the related ternary alloy systems $\mathrm{Al}-\mathrm{Cu}-\mathrm{Co}$ (see $[4,5]$ and references therein) and $\mathrm{Al}-\mathrm{Cu}-\mathrm{Rh}[6]$ were recently investigated $(\mathrm{Co}, \mathrm{Rh}$ and Ir belong to the same column of the periodic table). In the present communication we show the results concerning the phase equilibria in a compositional range of above 35 at. $\% \mathrm{Al}$ at $900^{\circ} \mathrm{C}$ and in a smaller compositional range close to the $\mathrm{Al}$ corner at $540^{\circ} \mathrm{C}$. The corresponding partial isothermal sections contain all four ternary phases revealed in [1]. The binary Al-Ir phase diagram was accepted from the recent update in [7], and the binary $\mathrm{Al}-\mathrm{Cu}$ phase diagram was accepted from [8].

\section{Experimental}

Alloys of 3 to $5 \mathrm{~g}$ were produced by levitation induction melting in a water-cooled copper crucible under a pure $\mathrm{Ar}$ atmosphere. The purity of $\mathrm{Al}$ was $99.999 \%$, of $\mathrm{Cu} 99.95 \%$, and of Ir $99.9 \%$. Parts of solidified ingots were thermally annealed under vacuum at $540^{\circ} \mathrm{C}$ for $232 \mathrm{~h}$ and at $900^{\circ} \mathrm{C}$ for 186 to $234 \mathrm{~h}$ and subsequently water quenched. The as-cast and annealed samples were studied by powder X-ray diffraction (XRD, $\mathrm{Cu} K \alpha_{1}$ radiation was used), scanning electron microscopy (SEM) and transmission electron microscopy (TEM). The local phase compositions were determined in SEM by energydispersive X-ray analysis (EDX) on polished unetched cross sections. TEM examinations were carried out on powdered materials dispersed on grids with carbon film. Differential thermal analysis (DTA) was carried out for selected samples at heating and cooling rates of 10 to $50^{\circ} \mathrm{C} / \mathrm{min}$.

\section{Results}

The Al-Ir alloy system [7] contains a number of intermetallics (see Table 1). Congruent AlIr ( $\beta$-phase) and congruent $\mathrm{C}-\mathrm{Al}_{2.7} \mathrm{Ir}$ (C-phase) melt at temperatures above 2000 and $1600^{\circ} \mathrm{C}$, respectively. At higher $\mathrm{Al}$ concentration the $\mathrm{Al}_{3} \mathrm{Ir}, \mathrm{Al}_{28} \mathrm{Ir}_{9}$ ( $\chi$-phase), $\mathrm{Al}_{45} \mathrm{Ir}_{13}$ ( $\varphi$-phase) and $\mathrm{Al}_{9} \mathrm{Ir}_{2}$ phases are formed by subsequent peritectic reactions at 1466, 1446, 993 and $877^{\circ} \mathrm{C}$. Finally, an $(\mathrm{Al})+\mathrm{Al}_{9} \mathrm{Ir}_{2}$ eutectic is formed at $657^{\circ} \mathrm{C}$. 
Table 1 Crystallographic data of the periodic Al-Cu, Al-Ir and Al-Cu-Ir phases mentioned in isothermal sections.

\begin{tabular}{|c|c|c|c|c|c|}
\hline \multirow[t]{2}{*}{ Phase } & \multirow[t]{2}{*}{ Space group } & \multicolumn{4}{|c|}{ Lattice parameters } \\
\hline & & $a, \mathrm{~nm}$ & $b, \mathrm{~nm}$ & $c, \mathrm{~nm}$ & $\beta,^{\circ}$ \\
\hline$\theta\left(\mathrm{Al}_{2} \mathrm{Cu}\right)$ & $\mathrm{I} 4 / \mathrm{mcm}$ & 0.60662 & - & 0.48738 & - \\
\hline$\eta_{2}(\mathrm{AlCu})$ & $C 2 / m$ & 1.2066 & 0.4105 & 0.6913 & 55.04 \\
\hline $\mathrm{Al}_{9} \mathrm{Ir}_{2}$ & $P 2_{1} / c$ & 0.63779 & 0.64318 & 0.87337 & 94.78 \\
\hline$\varphi\left(\mathrm{Al}_{45} \mathrm{Ir}_{13}\right)$ & Pnma & 1.6771 & 1.2327 & 1.7437 & - \\
\hline$\chi\left(\mathrm{Al}_{28} \mathrm{Ir}_{9}\right)$ & $P 31 c$ & 1.2286 & - & 2.7375 & - \\
\hline $\mathrm{Al}_{3} \mathrm{Ir}$ & $\mathrm{P6}_{3} / m m c$ & 0.4246 & - & 0.7756 & - \\
\hline $\mathrm{C}\left(\mathrm{Al}_{2.7} \mathrm{Ir}\right)$ & $P m \overline{3}$ & 0.7694 & - & - & - \\
\hline$\beta$ (AlIr) & $P m \overline{3} m$ & 0.2969 & - & - & - \\
\hline$\varepsilon_{6}{ }^{\mathrm{a}}$ & Orth. & 2.34 & 1.65 & 1.24 & - \\
\hline $\mathrm{C}_{2}$ & $F m \overline{3}$ & 1.53928 & - & - & - \\
\hline$\omega\left(\mathrm{Al}_{7} \mathrm{Cu}_{2} \mathrm{Ir}\right)$ & $P 4 / m n c$ & 0.64142 & - & 1.4842 & - \\
\hline
\end{tabular}

${ }^{\mathrm{a}}$ Electron diffraction data.

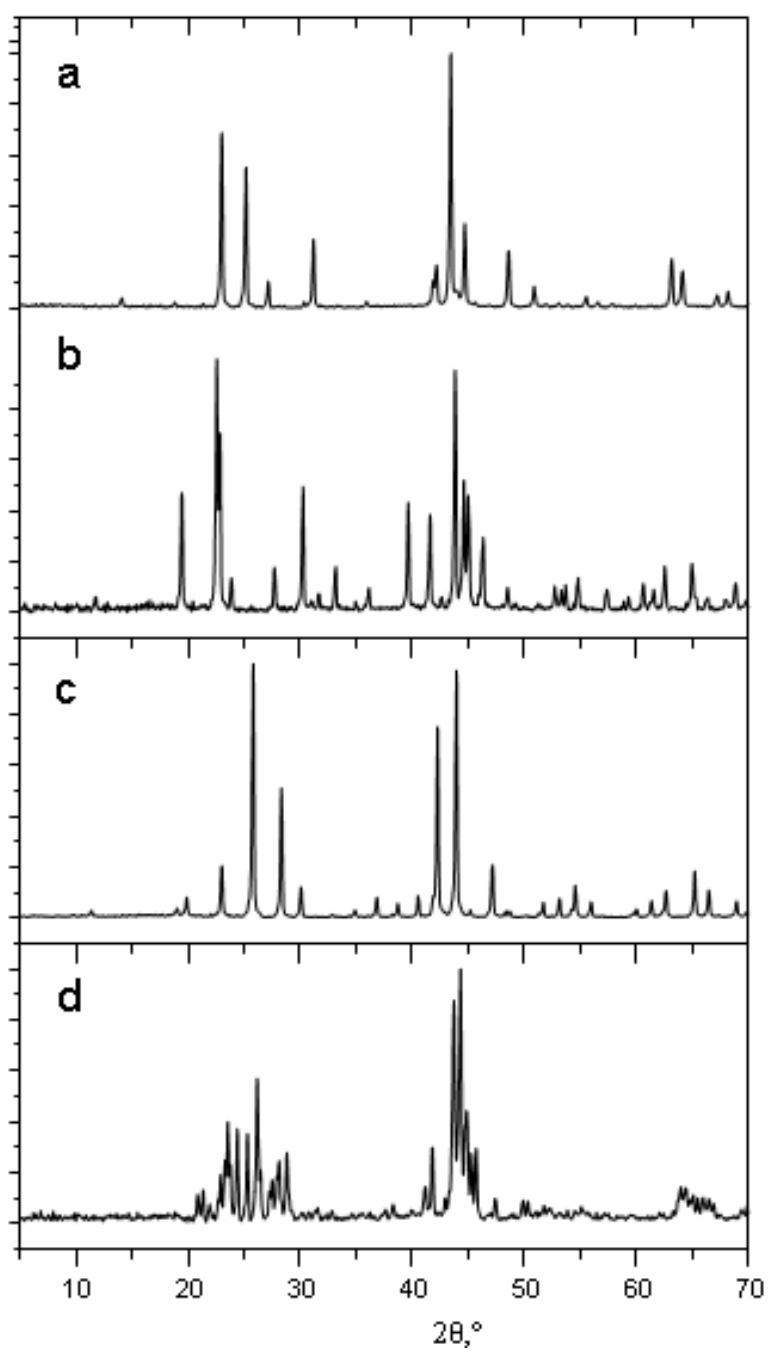

Fig. 1 Powder XRD patterns $\left(\mathrm{Cu} K \alpha_{1}\right.$ radiation) of the: a) decagonal phase $\left.\left(D_{1}\right), b\right) \omega-$ phase, c) $\mathrm{C}_{2}$-phase and d) $\varepsilon_{6}$-phase.

In $\mathrm{Al}-\mathrm{Cu}$ the phases forming in the relevant compositional range are high-temperature and lowtemperatures couples of the $\epsilon, \zeta$ and $\eta$ phases and
$\mathrm{Al}_{2} \mathrm{Cu}(\theta)$ [8]. Apart from $\epsilon_{1}$ they are molten at the temperature of $900^{\circ} \mathrm{C}$ selected for our major investigation. The $\theta$-phase presented in the partial $540^{\circ} \mathrm{C}$ isothermal section (see below) is formed by a peritectic reaction at $591^{\circ} \mathrm{C}$. The $(\mathrm{Al})+\theta$ eutectic is formed at $548^{\circ} \mathrm{C}$ [8]. The $\mathrm{Al}-\mathrm{Cu}$ phases were usually minor in the majority of the studied alloys and were identified according to their compositions compared to those in the binary phase diagram.

In solidified materials equiatomic AlIr was found to extend at approximately constant $\mathrm{Al}$ concentration up to 25 at. $\% \mathrm{Cu}$. The $\mathrm{C}$-phase dissolves up to 12 at.\% $\mathrm{Cu}, \mathrm{Al}_{3} \mathrm{Ir}$ up to 8.5 at. $\% \mathrm{Cu}$, the $\chi$-phase and $\varphi$-phase up to 3 at. $\% \mathrm{Cu}$, and $\mathrm{Al}_{9} \mathrm{Ir}_{2}$ up to 2.5 at. $\% \mathrm{Cu}$. With the increase of the $\mathrm{Cu}$ concentration the compositional ranges of the above-mentioned binary Al-Ir phases, apart from the $\beta$-phase, become wider and sharply shifted towards lower $\mathrm{Al}$ concentrations. The dissolution of $\mathrm{Cu}$ also results in a decrease of the melting temperatures of the Al-Ir phases.

The Al-Cu $\epsilon_{1}$-phase dissolves up to 3 at.\% Ir, while the solubility of Ir in $\theta$ and $\eta_{2}$ is below 0.5 at. $\%$.

The formation of a stable ternary decagonal phase and three ternary periodic phases was also observed in the above-mentioned compositional range. Their powder X-ray diffraction patterns are shown in Fig. 1. The decagonal phase of $\sim \mathrm{Al}_{60} \mathrm{Cu}_{24} \mathrm{Ir}_{16}$ examined by electron diffraction exhibited a periodicity of $\sim 0.4 \mathrm{~nm}$ in the specific direction $\left(\mathrm{D}_{1}\right.$-structure, Fig. $\left.2 \mathrm{a}-\mathrm{c}\right)$. Of the periodic phases, one was found around the $\mathrm{Al}_{70} \mathrm{Cu}_{20} \mathrm{Ir}_{10}$ composition ( $\omega$-phase, see Table 1 ). It is isostructural to the $\mathrm{Al}_{7} \mathrm{Cu}_{2} \mathrm{Rh} \omega$-phase, also observed at similar compositions in $\mathrm{Al}-\mathrm{Cu}-\mathrm{Co}(\mathrm{Fe}, \mathrm{Ru})$ [1]. The second ternary $\mathrm{C}_{2}$-phase (see Table 1 ) is formed in a range around $\mathrm{Al}_{61} \mathrm{Cu}_{13} \mathrm{Ir}_{26}$, i.e. close to the high- $\mathrm{Cu}$ limit of the $\mathrm{C}$-phase compositional range. It exhibits a structure typical of the $\mathrm{C}_{2}$-phases that are also formed in $\mathrm{Al}-\mathrm{Cu}-\mathrm{Rh}$ and a number of other aluminumtransition metal alloy systems [1]. Around the $\mathrm{Al}_{70} \mathrm{Cu}_{10} \mathrm{Ir}_{20}$ composition, the third ternary phase was revealed, which belongs to the family of so-called $\varepsilon_{i}$ phases [9]. Electron diffraction examinations in TEM 

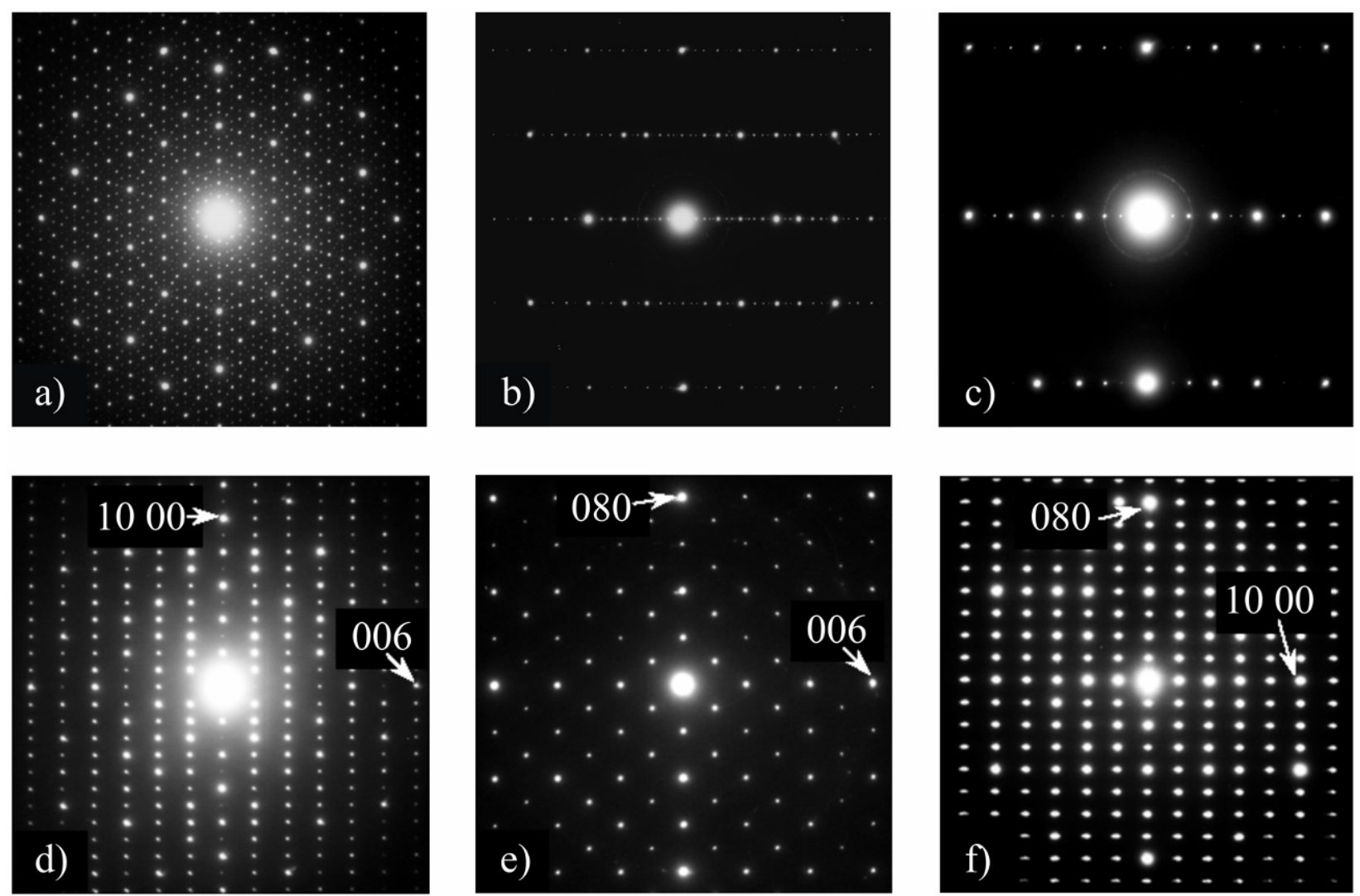

Fig. 2 Electron diffraction patterns of the Al-Cu-Ir phases: a-c) decagonal phase $\left.\left(D_{1}\right), d-f\right) \varepsilon_{6}$-phase.

(see Fig. 2d-f) revealed the $\varepsilon_{6}$ structure, also observed in $\mathrm{Al}-(\mathrm{Cu})-\mathrm{Rh}[6]$. While in binary $\mathrm{Al}-\mathrm{Rh}$ the $\varepsilon_{6}$-phase is stable and can dissolve up to $\sim 15$ at. $\% \mathrm{Cu}$, it does not exist as a stable phase in Al-Ir, but is stabilized by $\mathrm{Cu}$ in a ternary compositional range.

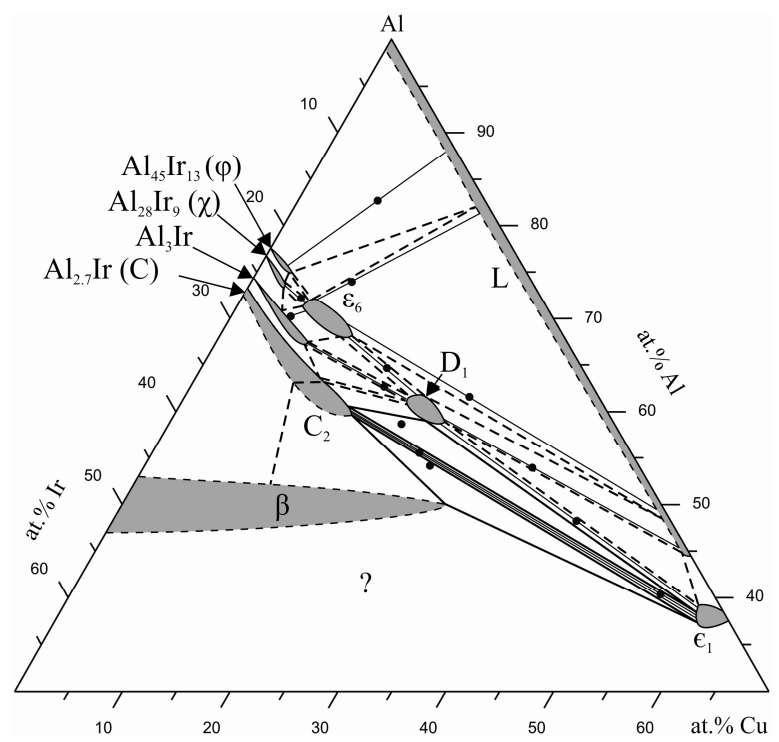

Fig. 3 Partial isothermal section at $900^{\circ} \mathrm{C}$. The compositions of the studied samples are shown by spots. Provisional tie-lines are shown by broken lines. $\mathrm{L}$ is liquid. The compositional region marked by (?) was not studied.
The $\mathrm{D}_{1}$-phase melts at about $1002^{\circ} \mathrm{C}$, the $\varepsilon_{6}$-phase at $\sim 1200^{\circ} \mathrm{C}$, the $\omega$-phase at $683^{\circ} \mathrm{C}$ whereas the $\mathrm{C}_{2}$-phase was not melted up to $1400^{\circ} \mathrm{C}$.

The partial $900^{\circ} \mathrm{C}$ isothermal section of $\mathrm{Al}-\mathrm{Cu}-\mathrm{Ir}$ is shown in Fig. 3. In the studied compositional range the Al-Ir phases $\beta, \mathrm{C}, \mathrm{Al}_{3} \mathrm{Ir}, \chi$ and $\varphi$ are solid at this temperature, while a wide region adjacent to $\mathrm{Al}-\mathrm{Cu}$ is occupied by the liquid and only the $\epsilon_{1}$-phase is solid. The ternary $\varepsilon_{6}$-phase is formed in a compositional range from $\mathrm{Al}_{71.5} \mathrm{Cu}_{6} \mathrm{Ir}_{22.5}$ to $\mathrm{Al}_{68} \mathrm{Cu}_{12.5} \mathrm{Ir}_{19.5}$. The $\mathrm{D}_{1}$-phase is also solid at this temperature and is formed in a compositional range from $\mathrm{Al}_{61.5} \mathrm{Cu}_{20} \mathrm{Ir}_{18.5}$ to $\mathrm{Al}_{59} \mathrm{Cu}_{25.5} \mathrm{Ir}_{15.5}$. The compositional gap between the existence regions of the $\mathrm{C}$-phase and $\mathrm{C}_{2}$-phase was not detected and the separation of their compositional ranges is shown conditionally in Fig. 3 by a broken line. It is worth noting that in the $\mathrm{Al}-\mathrm{Cu}-\mathrm{Rh}$ [6] and Al-Pd-Rh [10] alloy systems similar $C$ and $C_{2}$ phases were found to coexist in narrow ranges, which was very difficult to detect. The three-phase equilibria $\mathrm{Al}_{3} \mathrm{Ir}-\varepsilon_{6}-\chi, \quad \mathrm{Al}_{3} \mathrm{Ir}-\varepsilon_{6}-\mathrm{D}_{1}, \quad \mathrm{~L}-\varepsilon_{6}-\mathrm{D}_{1}$ and $\mathrm{L}-\epsilon_{1}-\mathrm{D}_{1}$ were established with certainty from the existence of the corresponding boundary two-phase equilibria. The three-phase equilibria between the $\varphi, \chi, \varepsilon_{6}$ phases and the liquid have not been clarified yet due to difficulties to obtain samples in the corresponding small compositional ranges. In Fig. 3 one of the possibilities is assumed.

The partial $540^{\circ} \mathrm{C}$ isothermal section is shown in Fig. 4. At this temperature equilibration of only a few alloys adjacent to the $\mathrm{Al}$ corner was achieved after a 


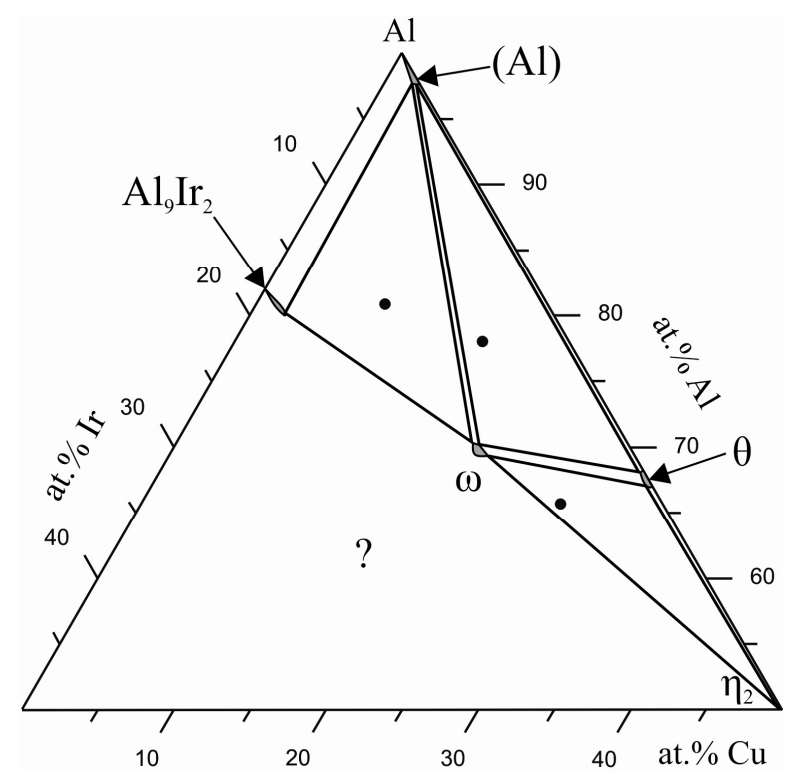

Fig. 4 Partial isothermal section at $540^{\circ} \mathrm{C}$. The compositions of the studied samples are shown by spots. Provisional tie-lines are shown by broken lines. $\mathrm{L}$ is liquid. The compositional region marked by (?) was not studied.

reasonable time. At this temperature the ternary $\omega$-phase is in equilibrium with the $\mathrm{Al}_{9} \mathrm{Ir}_{2},(\mathrm{Al}), \theta$ and $\eta_{2}$ phases.

\section{Conclusions}

We report a first study of the Al-Cu-Ir alloy system in the compositional range above 35 at.\% Al. Partial 900 and $540^{\circ} \mathrm{C}$ isothermal sections were determined. The
Al-Ir phases were found to dissolve $\mathrm{Cu}: 30$ at.\% for AlIr, 12, 8.5, 3, 3 and 2.5 at.\% for $\mathrm{Al}_{2.7} \mathrm{Ir}, \mathrm{Al}_{3} \mathrm{Ir}, \chi, \varphi$ and $\mathrm{Al}_{9} \mathrm{Ir}_{2}$, respectively. One stable ternary decagonal phase $\left(\mathrm{D}_{1}\right.$-phase $)$ and three ternary periodic phases designated $\mathrm{C}_{2}, \varepsilon_{6}$ and $\omega$ were revealed.

\section{Acknowledgements}

We thank V. Lenzen and M. Schmidt for technical contributions. D. Kapush and T.Ya. Velikanova thank Forschungszentrum Jülich for financial support.

\section{References}

[1] B. Grushko, D. Pavlyuchkov, Powder Diffr. 23 (2008) 356.

[2] N.S. Athanasiou, Int. J. Mod. Phys. B 11 (1997) 2443.

[3] B. Grushko, T. Velikanova, CALPHAD 31 (2007) 217.

[4] S. Mi, B. Grushko, C. Dong, K. Urban, J. Alloys Compd. 354 (2003) 148.

[5] L.M. Zhang, P. Gille, J. Alloys Compd. 370 (2004) 198.

[6] B. Grushko, W. Kowalski, B. Przepiórzyński, D. Pavlyuchkov, J. Alloys Compd. 464 (2008) 227.

[7] D. Pavlyuchkov, B. Grushko, T.Ya. Velikanova, Intermetallics 16 (2008) 801.

[8] J.L. Murray, In: P.R. Subramanian, D.J. Chakrabarti, D.E. Laughlin (Eds.), Phase Diagrams of Binary Copper Alloys, ASM International, Materials Park, OH, 1994, p. 18.

[9] S. Balanetskyy, B. Grushko, T.Ya. Velikanova, Z. Kristallogr. 219 (2004) 548.

[10] B. Przepiórzyński, B. Grushko, M. Surowiec, Intermetallics 14 (2006) 498. 